\title{
Soil Test based Fertilizer Recommendation for Mustard (Brassica juncea L.) in Eastern Plain Zone of Uttar Pradesh, India
}

\author{
M. Verma ${ }^{1}$, Y.V. Singh ${ }^{1} *$ P. Dey ${ }^{2}$ and A. Babu ${ }^{1}$ \\ ${ }^{1}$ AICRP, STCR, Department of Soil Science and Agricultural Chemistry, Institute of \\ Agricultural Sciences, Banaras Hindu University, Varanasi 221005 (Uttar Pradesh), India \\ ${ }^{2}$ STCR (AICRP), Indian Institute of Soil Science, Bhopal 462038 \\ (Madhya Pradesh), India \\ *Corresponding author
}

\section{A B S T R A C T}

Keywords

Mustard, Target yield, Fertilizer adjustment equations, Soil test, Crop response, etc.

Article Info

Accepted:

12 January 2017

Available Online:

10 February 2017
To study the soil test based fertilizer recommendation for mustard crop on grain and straw yield, nutrient uptake and soil test data were used for obtaining basic parameter viz., Nutrient requirement, contribution of nutrients from soil, fertilizer and organic manure. It was found that $5.22 \mathrm{~kg} \mathrm{~N}, 0.99 \mathrm{~kg} \mathrm{P}_{2} \mathrm{O}_{5}$ and $4.25 \mathrm{~kg} \mathrm{~K} \mathrm{~K}_{2} \mathrm{O}$ were required for producing one quintal of grain. The per cent contribution of soil nitrogen, phosphorus and potassium were $23.94,70.45$ and 22.14 the percent contribution from applied fertilizer were 42.53, 21.44 and 90.52 per cent of nitrogen, phosphorus and potassium respectively. The fertilizer adjustment equation were developed for mustard (var. Ashirwad) and quantitative estimation of fertilizer doses formulated for a range of soil test values and desired yield targets under NPK alone and with FYM.

\section{Introduction}

Rapeseed-mustard is the second most important oilseed crop in India. Its production has markedly increased after launching of Technology Mission on Oilseeds. However, its productivity is only $1128 \mathrm{~kg} \mathrm{ha}^{-1}$ and in Uttar Pradesh Rapeseed and mustard occupies $1.0 \mathrm{mha}$ area with production of $1.12 \mathrm{mt}$. in 2013-14 (GOI). Over-exploitation of soils over many decades has resulted in the exhaustion of the agricultural production systems and steadily declining productivity has been noticed in long term experiments in Asia (Bhandari et al., 2002; Latha et al.,
2003; Manna et al., 2005). The decision on fertilizer use requires knowledge of the expected crop yield response to nutrient application, which is a function of crop nutrient needs, supply of nutrients from indigenous sources, and the fate of the fertilizer applied (Dobermann et al., 2003). The cost of fertilizers has gone up and, hence, their optional use in required quantity mainly depends on resources available to farmers. Imbalanced use of chemical fertilizers results in lower nutrient use efficiency and restricts utilization of the genetic potential of a crop to 
its maximum. The most comprehensive approach of fertilizer application by incorporating soil test values, nutrient requirement of the crop, contribution of nutrients from soil manures fertilizers and fixing yield targets is possible only through the fertility gradient field experimental technique of Ramamoorthy et al., (1967). Soil test based application of plant nutrient helps to realize higher response ratio and benefit: cost ratio as the nutrients are applied in proportion to the magnitude of the deficiency of a particular nutrient and the correction of the nutrients imbalance in soil helps to harness the synergistic effects of balanced fertilization (Rao and Srivastava, 2000). Balanced fertilization can be only option to mitigate this anomaly and it does not only mean the application of right quantity of fertilizers for crop growth, but also the right time, mode and sources of application. The nutrient management strategies involving the use of chemical fertilizers but also supplemented with organic manure and bio fertilizers. The present investigation aimed to study the relationship between the nutrient supplied by the soil and added fertilizers, their uptake and yield of mustard and to develop a guideline for judicious application of fertilizer for maximum production of mustard.

\section{Materials and Methods}

A field experiment on Soil test based fertilizer recommendation with mustard (Brassica juncea L.) was conducted at Agricultural Research Farm, Banaras Hindu University, Varanasi, Uttar Pradesh during rabi 201415.The Selected site of experiment was 52.90 x 24.0 square meter dimensions and was divided into three strips of equal size and the three fertility gradients designated as $0_{\mathrm{A}}, 1_{\mathrm{A}}$ and $2_{\mathrm{A}}$ were developed by applying variable amounts of farmyard manure and $\mathrm{N}, \mathrm{P}$ and $\mathrm{K}$ fertilizer. Rice was taken as an exhaustive crop for stabilization of the fertility gradients create the wide variation in soil fertility for attainment of successful soil test crop response correlation and to minimize the interference of other soil and management factors affecting crop yield. In the main experiment each strip was further sub-divided into twenty four equal plot of $3 \times 3.5 \mathrm{sq}$. m size having twenty one treated and three control plots. The mustard was sown in lines $45 \mathrm{~cm}$ apart, under selected treatment combinations four level of each $\mathrm{N}(0,40,80$ and $120 \mathrm{~kg}$ ha $\left.{ }^{1}\right), \mathrm{P}_{2} \mathrm{O}_{5}\left(0,20,40\right.$ and $\left.60 \mathrm{~kg} \mathrm{ha}^{-1}\right), \mathrm{K}_{2} \mathrm{O}(0,20$, 40 and $60 \mathrm{~kg} \mathrm{ha}^{-1}$ ) and three levels of FYM $\left(0,5\right.$ and $\left.10 \mathrm{t} \mathrm{ha}^{-1}\right)$. Soil sample were taken from surface layer $(0-15 \mathrm{~cm})$ from each plot of strip I, II and III before fertilizer treatment application. The samples collected from the field were brought to the laboratory and kept in air drying for laboratory analysis. The initial soil samples were analyzed for organic carbon (Walkley and Blak, 1934), Alkaline $\mathrm{KMnO}_{4}$ oxidizable nitrogen (Subbiah and Asija, 1956), Olsen's phosphorus (Olsen et $a l ., 1954)$ and ammonium acetate extractable potassium (Hanway and Heidal, 1952). At crop maturity, the plot wise yield was recorded and composite plant samples (grain and straw) were collected and processed. These samples were analyzed far total N, P and K contents (Jackson, 1973). These soil test data, plant analysis and grain yield data as given in table 2 were used to develop fertilizer prescription equation as per method described by Ramamoorthy et al. (1967).

1. Fertilizer requirement equation for target yield through fertilizer only

$\mathrm{FD}=\frac{\mathrm{NR}}{\% \mathrm{CF}} \times 100 \mathrm{~T}-\frac{\% \mathrm{CS}}{\% \mathrm{CF}} \times \mathrm{STV}$

2. Fertilizer requirement equation for target yield through fertilizer and FYM

$\mathrm{FD}=\frac{\mathrm{NR}}{\% \mathrm{CF}} \times 100 \mathrm{~T}-\frac{\% \mathrm{CS}}{\% \mathrm{CF}} \mathrm{XSTV}-\frac{\% \mathrm{CFYM}}{\% \mathrm{CF}} \mathrm{XM}$ 
Where,

FD $=$ Fertilizer dose of nitrogen, phosphorus and potassium in $\mathrm{kg} \mathrm{ha}{ }^{-1}, \mathrm{NR}=$ Nutrient requirement $(\mathrm{kg})$ of nitrogen, phosphorus and potassium, $\mathrm{CS}=$ Contribution of nutrients from soil nutrient $(\%), \mathrm{CF}=$ Contribution of nutrients from applied fertilizer soil nutrient (\%), CFYM = Contribution of nutrients from applied organic manure $(\%), \mathrm{T}=$ Yield target $\mathrm{kg} \mathrm{ha}{ }^{-1}, \mathrm{M}=$ Amount of nutrient applied through FYM $\left(\mathrm{kg} \mathrm{ha}{ }^{-1}\right)$, STV = Soil test values $\left(\mathrm{kg} \mathrm{ha}^{-1}\right)$.

A multiple regression equation was calibrated to predict the expected yield levels under varying levels of nutrients supplied through soil and fertilizers as well as their interactions and is given below as:

$\mathrm{Y}= \pm \mathrm{A} \pm \mathrm{b} 1 \mathrm{SN} \pm \mathrm{b} 2 \mathrm{SN} 2 \pm \mathrm{b} 3 \mathrm{SP} \pm \mathrm{b} 4 \mathrm{SP} 2 \pm$ b5 SK \pm b6 SK2 \pm b7 FN \pm b8FN2 \pm b9 FP $\pm \mathrm{b} 10 \mathrm{FP} 2 \pm \mathrm{b} 11 \mathrm{FK} \pm \mathrm{b} 12 \mathrm{FK} 2 \pm \mathrm{b} 13 \mathrm{FNSN} \pm$ b14 FPSP \pm b15FKSK Where, $Y=$ crop yield $\left(\mathrm{kg} \mathrm{ha}{ }^{-1}\right) ; \mathrm{A}=$ intercept $\left(\mathrm{kg} \mathrm{ha}^{-1}\right) ; \mathrm{bi}=$ regression coefficient $\left(\mathrm{kg} \mathrm{ha}^{-1}\right) ; \mathrm{SN}, \mathrm{SP}, \mathrm{SK}=$ available soil nitrogen, phosphorus and potassium $\left(\mathrm{kg} \mathrm{ha}^{-1}\right)$ respectively; FN, FP, FK= fertilizer nitrogen, phosphorus and potassium $\left(\mathrm{kg} \mathrm{ha}^{-1}\right)$ respectively.

\section{Results and Discussion}

The experimental field was having wide variability in soil test values which was necessary before conducting this experiment. The strip wise ranges and means of grain yield and soil test values of organic carbon, nitrogen, phosphorus and potassium are given in table 1 .

The average organic carbon content of entire experimental area, varied from 0.31 to 0.91 percent with a mean of 0.68 percent. The available nitrogen of the entire experimental plots ranged between 195 and $267.38 \mathrm{~kg} \mathrm{~N}$ ha 1 , with mean value $239.37 \mathrm{~kg} \mathrm{~N} \mathrm{ha}^{-1}$. The available phosphorus content of the entire experimental field ranged from 14.50 to 28.75 $\mathrm{kg} \mathrm{P}_{2} \mathrm{O}_{5} \mathrm{ha}^{-1}$, with a mean value of $20.29 \mathrm{~kg}$ $\mathrm{P}_{2} \mathrm{O}_{5} \mathrm{ha}^{-1}$. The available potassium ranged from 183.0 to $256.0 \mathrm{~kg} \mathrm{~K}_{2} \mathrm{O} \mathrm{ha}^{-1}$, mean being $221.90 \mathrm{~kg} \mathrm{~K}_{2} \mathrm{O} \mathrm{ha}^{-1}$ for the entire experimental area. The average grain yield in I, II and III strips was recorded as 15.74, 16.65 and $17.75 \mathrm{q} \mathrm{ha}^{-1}$ and the average straw yield in I, II and III strips was recorded as 43.39, 44.63 and $46.75 \mathrm{q} \mathrm{ha}^{-1}$ respectively.

The basic data regarding calculation of fertilizer doses for targeted yield of mustard is presented in table 2 . The nutrient requirement for the production of one quintal of grain 5.22 $\mathrm{kg}$ of nitrogen $(\mathrm{N}), 0.99 \mathrm{~kg}$ of phosphorus $\left(\mathrm{P}_{2} \mathrm{O}_{5}\right)$ and $4.25 \mathrm{~kg}$ of potassium $\left(\mathrm{K}_{2} \mathrm{O}\right)$ were required. The percentage contribution from soil as its available nutrients in case of nitrogen was 23.94, for phosphorus 70.45 and for potassium 22.14 and the percent contribution from applied fertilizer with FYM was 42.53, 21.44 and 90.52 percent of nitrogen, phosphorus and potassium, respectively.

Avtari et al., (2010) were reported $5.08 \mathrm{~kg}$ of nitrogen, $1.24 \mathrm{~kg}$ of phosphorus and $3.96 \mathrm{~kg}$ of potassium required for producing one quintal grain of yellow sarson and the percent contribution of nutrients from soil in case of nitrogen was 33.89, for phosphorus 52.99 and for potassium 16.38 and the percent contribution from applied fertilizer with FYM was $32.50,51.50$ and 101.95 percent of nitrogen, phosphorus and potassium respectively in soils of tarai region of Uttar Pradesh. Similar result was also reported by Regar and singh (2014) and Sachan et al., (1981).

The following simplified fertilizer adjustment equations was formulated by using basic data to give the fertilizer dose, as a function of targeted yield and soil test values. 


\section{With FYM}

1. Nitrogen dose $\left(\mathrm{kg} \mathrm{ha}^{-1}\right)=12.27 \mathrm{~T}-0.56 \mathrm{SN}$ 0.09FYM-N

2. Phosphorus dose $\left(\mathrm{kg} \mathrm{ha}^{-1}\right)=4.60 \mathrm{~T}-3.29 \mathrm{SP}$ 0.06FYM-P

3. Potassium dose $\left(\mathrm{kg} \mathrm{ha}^{-1}\right)=4.69 \mathrm{~T}-0.24 \mathrm{~K}-$ 0.05FYM-K

\section{Without FYM}

1. Nitrogen dose $\left(\mathrm{kg} \mathrm{ha}^{-1}\right)=12.27 \mathrm{~T}-0.56 \mathrm{SN}$

2. Phosphorus dose $\left(\mathrm{kg} \mathrm{ha}^{-1}\right)=4.60 \mathrm{~T}-3.29 \mathrm{SP}$

3. Potassium dose $\left(\mathrm{kg} \mathrm{ha}^{-1}\right)=4.69 \mathrm{~T}-0.24 \mathrm{~K}$
$\mathrm{T}=$ Yield target $\left(\mathrm{q} \mathrm{ha}^{-1}\right), \mathrm{SN}=$ Alkaline $\mathrm{KMnO}_{4}-\mathrm{N}, \mathrm{SP}=$ Olsen's $\mathrm{P}\left(\mathrm{kg} \mathrm{ha}^{-1}\right)$ and $\mathrm{S}_{\mathrm{k}}+$ Amm. Ac.- K $\left(\mathrm{kg} \mathrm{ha}^{-1}\right)$.

The fertilizer adjustment equations were ready for determining requirement of fertilizer. Say for $18 \mathrm{q} \mathrm{ha}^{-1}$ the yield target of mustard with varying soil test values in table 3. These results were shows that the fertilizer requirement varies with the soil test values for a particular target yield. Similar result was also reported by Mishra et al. (2014) and Singh et al. (2014).

Table.1 Range and average of mustard yield ( $\left.\mathrm{q} \mathrm{ha}^{-1}\right)$ and soil test values under different fertility strips

\begin{tabular}{|c|c|c|c|c|c|c|}
\hline \multirow[t]{2}{*}{ Particulars } & \multicolumn{2}{|c|}{ Strip I } & \multicolumn{2}{|c|}{ Strip II } & \multicolumn{2}{|c|}{ Strip III } \\
\hline & Range & Mean & Range & Mean & Range & Mean \\
\hline Grain yield $\left(\mathrm{q} \mathrm{ha}^{-1}\right)$ & $12.0-19.80$ & $15.74 \pm 0.43$ & $12.80-20.80$ & $16.65 \pm 0.44$ & $13.90-22.50$ & $17.75 \pm 0.45$ \\
\hline Organic carbon $(\%)$ & $0.41-0.71$ & $0.54 \pm 0.02$ & $0.45-0.83$ & $0.68 \pm 0.02$ & $\begin{aligned} 0.65-0.91 \\
24053\end{aligned}$ & $0.81 \pm 0.01$ \\
\hline $\begin{array}{l}\text { Alkaline } \\
\left(\mathrm{kg} \mathrm{ha}^{-1}\right)\end{array} \quad \mathrm{KMnO}_{4}-\mathrm{N}$ & 195.0-239.07 & $221.41 \pm 2.37$ & $212.0-254.79$ & $239.69 \pm 2.18$ & $\begin{array}{l}240.53- \\
267.34\end{array}$ & $257.02 \pm 1.56$ \\
\hline Olsen's P $\left(\mathrm{kg} \mathrm{ha}^{-1}\right)$ & $14.50-20.22$ & $17.52 \pm 0.32$ & $14.80-22.35$ & $19.03 \pm 0.40$ & 207.54 & $24.36 \pm 0.53$ \\
\hline Am. Ac K $\left(\mathrm{kg} \mathrm{ha}^{-1}\right)$ & $183.0-220.12$ & $202.36 \pm 2.08$ & $183.0-240.0$ & $220.54 \pm 3.04$ & $\begin{array}{l}19.50-20.15 \\
188.0-256.0 \\
\end{array}$ & $240.81 \pm 3.48$ \\
\hline
\end{tabular}

Table.2 Basic data for calculating fertilizer doses with and without FYM for targeted yields of mustard

\begin{tabular}{|l|c|c|c|c|c|c|}
\hline Particulars & \multicolumn{2}{|c|}{ Without FYM } & \multicolumn{3}{c|}{ With FYM } \\
\cline { 2 - 7 } & $\mathrm{N}$ & $\mathrm{P}$ & $\mathrm{K}$ & $\mathrm{N}$ & $\mathrm{P}$ & $\mathrm{K}$ \\
\hline $\begin{array}{l}\text { Nutrient requirement }(\mathrm{kg}) \text { to produce one } \\
\text { quintal of mustard grain. }\end{array}$ & 5.22 & 0.99 & 4.25 & 5.22 & 0.99 & 4.25 \\
$\begin{array}{l}\text { Percent contribution from soil as its available } \\
\text { nutrients (CS)* }\end{array}$ & 23.94 & 70.45 & 22.14 & 23.94 & 70.45 & 22.14 \\
$\begin{array}{l}\text { Percent contribution from applied fertilizer } \\
\text { nutrients with FYM(CF) }\end{array}$ & 42.53 & 21.44 & 90.52 & 42.53 & 21.44 & 90.52 \\
$\begin{array}{l}\text { Percent contribution from applied FYM } \\
\text { nutrients (CFYM }\end{array}$ & - & - & - & 4.02 & 1.24 & 4.96 \\
\hline
\end{tabular}

*Soil tests values at $(0-15 \mathrm{~cm}$ depth) Alkaline KMnO4 -N (kg ha-1), Olsen's-P (kg ha-1) and neutral normal ammonium acetate extractable potassium $\left(\mathrm{kg} \mathrm{ha}^{-1}\right)$ 
Table.3 Estimation of soil test based fertilizer recommendation for $18 \mathrm{q} \mathrm{ha}^{-1}$ grain yield target of mustard crop

\begin{tabular}{|c|c|c|c|c|c|c|c|c|}
\hline \multicolumn{3}{|c|}{ Soil test values $\left(\mathrm{kg} \mathrm{ha}^{-1}\right)$} & \multicolumn{2}{l|}{$\begin{array}{l}\text { Fertilizer } \\
\text { under NPK alone }\end{array}$} \\
\hline SN & SP & SK & FN & $\mathrm{F} \mathrm{P}_{2} \mathrm{O}_{5}$ & $\mathrm{~F} \mathrm{~K}_{2} \mathrm{O}$ & FN & $\mathrm{F} \mathrm{P}_{2} \mathrm{O}_{5}$ & $\mathrm{~F} \mathrm{~K}_{2} \mathrm{O}$ \\
\hline 140 & 10 & 140 & 142.46 & 51.70 & 142.46 & 137.96 & 48.10 & 56.02 \\
160 & 12 & 160 & 131.26 & 45.12 & 131.26 & 126.76 & 41.52 & 51.22 \\
180 & 14 & 180 & 120.06 & 38.54 & 120.06 & 115.56 & 34.94 & 46.42 \\
200 & 16 & 200 & 108.86 & 31.96 & 108.86 & 104.36 & 28.36 & 41.62 \\
220 & 18 & 220 & 97.66 & 25.38 & 97.66 & 93.16 & 21.78 & 36.82 \\
240 & 20 & 240 & 86.46 & 18.80 & 86.46 & 81.96 & 15.20 & 32.02 \\
260 & 22 & 260 & 75.26 & 12.22 & 75.26 & 70.76 & 8.62 & 27.22 \\
\hline
\end{tabular}

Table.4 Prediction equations for post-harvest soil test value for mustard crop

\begin{tabular}{|c|c|c|}
\hline Nutrient & Multiple regression equation & $\mathbf{R}^{\mathbf{2}}$ \\
\hline $\mathbf{N}$ & $\mathrm{PHN}=185.65+2.224 \mathrm{RY} * *+0.098 \mathrm{SN} * *+0.176 \mathrm{FN} *$ & $0.67 * *$ \\
\hline $\mathbf{P}$ & $\mathrm{PHP}=14.89+0.840 \mathrm{RY} *+0.4422 \mathrm{SP} * *+0.0630 \mathrm{FP} * *$ & $0.82 * *$ \\
\hline $\mathbf{K}$ & $\mathrm{PHK}=131.18+3.6215 \mathrm{RY} * *+0.117 \mathrm{SK} * *+0.0792 \mathrm{FK}$ & $0.88^{* *}$ \\
\hline
\end{tabular}

Where: SN, SP, SK; soil available nitrogen, phosphorus $\left(\mathrm{P}_{2} \mathrm{O}_{5}\right)$ and potassium $\left(\mathrm{K}_{2} \mathrm{O}\right)\left(\mathrm{kg} \mathrm{ha}^{-1}\right)$; FN, FP and FK; fertilizer nitrogen, phosphorus and potassium $\left(\mathrm{K}_{2} \mathrm{O}\right)$ required $\left(\mathrm{kg} \mathrm{ha}^{-1}\right)$. RY is relative yield $\left(\mathrm{kg} \mathrm{ha}^{-1}\right) ; * *$ significant at $1 \%$ level.

The prediction equation for a post-harvest soil test value can be used to make a fertilizer recommendation for entire cropping system. This is very useful because the soil of farmers' fields under intensive cultivation cannot be tested for each crop for practical reasons. The interaction with the initial soil test values, post-harvest soil test values, fertilizer applied doses and grain yield from the treated plots for mustard crop are presented in table 4 . Considerable large $\mathrm{R}^{2}$ values (significant at $1 \%$ ) were obtained. This suggests that such regression equations can be used with confidence for the prediction of available $\mathrm{N}, \mathrm{P}$ and $\mathrm{K}$ after mustard for making soil test based fertilizer recommendation for succeeding crops. Similar results were also found by Singh et al., (2015) and Milapchand et al., (2006) for the three major nutrients.

In conclusion, targeted yield approach in the present study showed difference in fertilizer requirement of nitrogen, phosphorus and potassium, which needs to be further investigation needed over the farmer's own practice and general fertilizer recommendation. It is also suggested that the trends observed in this study may hold true for broad generalization in the larger parts of the Gangatic eastern plains that would serve as potent guide for efficient fertilizer management. Involvement of both soil and plant analysis make fertilizer 
recommendations based on this concept are more quantitative, precise and meaningful. This provides the scientific basis for balanced fertilization and enables farmer to choose target yield according to his resource and management conditions.

\section{Acknowledgements}

The authors are grateful to Indian Institute of Soil Sciences, Bhopal for providing financial assistance through AICRP on STCR project during the course of investigation.

\section{References}

Avtari, S., Singh, S. and Kumar, S. 2010. Fertilizer prescription for target yield of yellow sarson Brassica rapa var PYS 1) in mollisols of Utarakhand. Pantnagar J. Res., 8: 2-6.

Bhandari, A.L., Ladha, J.K., Pathak, H., Padre, A.T., Dawae, D. and Gupta, R.K. Soil nutrient changes in a long-term rice-wheat rotation in India. Soil Sci. Soc. America J., 58: 185-193.

Dobermann, A., Witt, C., Abdulrachman, S., Gines, H.S., Nagarajan, R., Son, T.T., Tan, P.S., Wang, G.H., Chien, N.V., Thoa, V.T.K., Phung, C.V., Stalin, P., Muthukrishnan, P., Ravi, V., Babu, M., Simbahan, G.C. and Adviento, M.A. 2003. Soil fertility and indigenous nutrient supply in irrigated rice domains of Asia. Agronomy J, 95: 913-923.

Hanway, T.J. and Heidal, H. 1952. Soil analysis methods as used in Iowa State soil testing laboratory. Iowa Agri., 57: 1-31.

Jackson, M.L. 1973. Soil chemical analysis. Prentice Hall of India Pvt. Ltd., New Delhi.

Latha, K.R. and Singh, R. 2003. Effect of cropping systems and fertilizer levels on the nutrient uptake and yield by sorghum in rainfed vertisols. Indian J.
Agri. Res., 37: 209-213.

Manna, M.C., Swarup, A., Wanjari, R.H., Ravankar, H.N., Mishra, B., Saha, M.N., Singh, Y.V., Sahi, D.K. and Sarap, P.A. 2005. Long-term effect of fertilizer and manure application on soil organic carbon storage, soil quality and yield sustainability under sub-humid and semi-arid tropical India. Field Crops Res., 93: 264-280.

Milap-Chand, Benbi, D.K. and Benipal, D.S. 2006. Fertilizer recommendations based on soil test for yield targets of mustard and rapeseed and their validation under farmers' field condition in Punjab. $J$. Indian Soc. Soil Sci., 54: 316-321.

Mishra, S., Singh, Y.V. and Dey, P. 2015. Quantitative estimation of fertilizer requirement for chickpea in the alluvial soil of the Indo-Gangetic plains. The Bioscan, 10: 435-438.

Olsen, S.R., Cole, C.V., Watanbe, F.S. and Dean, L.A. 1954. Estimation of available phosphorus in soil by extracting with sodium bicarbonate. U.S.A. Circ. 939. (c.f. methods of soil analysis, part 2. Ed. C. A. Black. American Society of Agronomy, Madison, Wisconsin).

Ramamoorthy, B., Narasimham, R.L. and Dinesh, R.S. 1967. Fertilizer application for specific yield target of sonara-64 wheat. Indian Farming, 17: 43-45.

Rao, S. and Srivastava. S. 2000. Soil test based fertilizer use-a must for sustainable agriculture. Fertilizer News, 45: 25-38.

Regar, K.L. and Singh, Y.V. 2014. Fertilizer recommendation based on soil testing for the targeted yield of rice in eastern plain zone of Uttar Pradesh. J. Bioscan, 9: 531-534.

Sachan, R.S., Gupta, R.A., Ram, N. and Ram, B. 1981. Fertilizer requirement of laha (Brassica juncia) for pre-set yield targets tarai soils of Uttar 
Pradesh. Indian J. Agri. Res., 15: 193196.

Singh, Y.V., Parihar, M., Singh, S.K., Sharma, P.K. and Dey P. 2015. Soil test based fertilizer prescriptions under integrated plant nutrient management system for maize in an inceptisol of Varanasi. J. Indian Society of Soil Sci., 63: 83-87.

Singh, Y.V., Singh, S.K., Sharma, P.K. and Singh, P. 2014. Soil test based integrated fertilizer recommendation for wheat (triticum aestivum) in an inceptisols of eastern plain zone of Uttar Pradesh. J. Indian Soc. Soil Sci., 62: 255-258.

Subbiah, B.V. and Asija, G.L. 1956. A rapid procedure for assessment of available nitrogen to rice plots. Curr. Sci., 31: 196-200.

Walkley, A. and Black, C.A. 1934. An examination of degtazreff method for determining soil organic matter and a proved modification of chronic acid titration method. Soil Sci., 37: 29-38.

\section{How to cite this article:}

Verma, M., Y.V. Singh, P. Dey and Babu, A. 2017. Soil Test based Fertilizer Recommendation for Mustard (Brassica Juncea L.) in Eastern Plain Zone of Uttar Pradesh, India. Int.J.Curr.Microbiol.App.Sci. 6(2): 155-161. doi: http://dx.doi.org/10.20546/ijcmas.2017.602.022 